\title{
Celiac disease associated with primary biliary cirrhosis in a Coast Salish native
}

\author{
HUGH J FREEMAN MD
}

\begin{abstract}
HJ FREEMAN. Celiac disease associated with primary biliary cirrhosis in a Coast Salish native. Can J Gastroenterol 1994;8(2):105-107. A 41-year-old Coast Salish female was initially diagnosed with typical features of classical adult celiac disease. Clinical and pathological features of primary biliary cirrhosis were also present, along with a familial history of insulin-dependent diabetes. Later, childhood celiac disease was detected in a male first-degree relative with diabetes. These patients are the first reported natives in Canada with celiac disease, a disorder believed to be genetically based but dependent on environmental factors for its clinical expression. The recognition of a 'new' disease in the setting of an aboriginal population may reflect geographical and climatic factors that permitted subsistence of this culturally complex food-gathering society up until most recent historical times, followed by adaptation of this society to European-based agricultural methods, particularly wheat cultivation.
\end{abstract}

Key Words: Antimitochondrial antibodies, Celiac disease epidemiology, Liver disease, Malabsorption, Native celiac disease, Primary biliary cirrhosis

\section{Maladie coeliaque associée à une cirrhose primaire chez une autochtone Salish de la côte ouest}

RÉSUMÉ : Une patiente Salish, de la côte ouest, a d'abord reçu un diagnostic de maladie coeliaque de l'adulte. Des caractéristiques cliniques et parhologiques de cirrhose biliaire primaire étaient également présentes, de même que des antécédents familiaux de diabète insulino-dépendant. Par la suite, une maladie coeliaque infantile a été décelée chez un parent du premier degré atteint de diabète. Ces deux sujets sont les deux premiers autochtones du Canada chez qui le diagnostic de maladie coeliaque est déclaré; cette affection avait longtemps été considérée avant tout génétique, quoique dépendante de facteurs environnementaux pour son expression clinique. L'observation d'une "nouvelle» maladie chez une population aborigène pourrait signaler le rôle de facteurs géographiques et climatiques dans la survie de cette complexe société encore non agraire, jusqu'à très récemment, et qui a dû s'adapter aux méthodes agricoles d'origine européenne, particulièrement à la culture du blé.

Department of Medicine (Gastroenterology), University Hospital and University of British Columbia, Vancouver, British Columbia

Correspondence and reprints: Dr Hugh Freeman, Head, Gastroenterology, ACU F-137, University Hospital (UBC Site), 2211 Wesbrook Mall, Vancouver, British Columbia V6T IW5. Telephone (604) 822-7216

Received for publication July 9, 1993. Accepted July 30, 1993
E PIDEMIOLOGICAL STUDIES ON THE geographical distribution of celiac disease suggest that it occurs almost exclusively in Europeans and their descendants, particularly those who have emigrated to North America and Australia (1). In Ireland, for example, the prevalence of clinically apparent celiac disease is estimated to be as high as one in 300 (2). Interestingly, there is a very high frequency of human leukocyte B8 antigen in western Ireland, a genetic marker known to be linked to a number of disorders, including celiac disease. In addition, there is a very long agricultural history of wheat cultivation in Europe dating from at least $1000 \mathrm{BC}$ (3). Such genetic and environmental factors appear to have played a critically important role in the clinical expression of celiac disease in different populations (4).

While recent epidemiological studies of celiac disease in Europe and other Mediterranean countries have been reported (5), this disorder has also been widely recognized in inhabitants from a number of other non-European countries (1) and has occasionally been detected in other non-Caucasian races, including possibly Blacks $(6,7)$, but not in Asians (8). Although both genetic and environmental factors are important (4), the very low case fatality rate of celiac disease, its relative rarity in most populations and wide variations in case ascertainment methods for dif- 
ferent countries have made epidemiological studies of celiac disease more difficult (9). It has been estimated, for example, that up to one-half of all adult celiac patients identified in some populations have few or no symptoms (9); obviously, then, case ascertainment would substantially influence differences in prevalence rates for celiac disease that might be reported from different centres. Additional studies are required, therefore, to map more precisely the epidemiological topography of celiac disease on a global scale.

This report documents an adult Coast Salish female with celiac disease, and explores possible environmental factors that may be significant historically in the appearance of a 'new disease' in the native peoples of British Columbia.

\section{CASE PRESENTATION}

A 41-year-old Coast Salish female was referred because of weight loss of 18 $\mathrm{kg}$. She also had pruritus, and her family physician found altered liver chemistry results including: alkaline phosphatase, $906 \mathrm{IU} / \mathrm{L}$ (normal 23 to 103 ); total bilirubin, $21 \mu \mathrm{mol} / \mathrm{L}$ (normal 2 to 17); and aspartate aminotransferase, $186 \mathrm{IU} / \mathrm{L}$ (normal 5 to 52 ). Other laboratory studies showed a mild hypochromic, microcytic anemia with: hemoglobin, $113 \mathrm{~g} / \mathrm{L}$ (normal 118 to 154 ); erythrocyte sedimentation rate, 43 $\mathrm{mm} / \mathrm{h}$ (normal 0 to 20); ferritin, 9 $\mathrm{nmol} / \mathrm{L}$ (normal 25 to 250 ); INR, 0.8 (normal 0.9 to 1.2 ); cholesterol, 7.74 $\mathrm{mmol} / \mathrm{L}$ (normal 3.36 to 5.19 ); total protein, $82 \mathrm{~g} / \mathrm{L}$ (normal 61 to 78 ); albumin, $38 \mathrm{~g} / \mathrm{L}$ (normal 35 to 55 ). Serological studies for hepatitis A, B and C viruses were negative and an abdominal ultrasound was normal.

Further studies following referral revealed positive antimitochondrial and smooth muscle antibodies (both in titres of 1:640); an elevated serum immunoglobulin M level of $4.24 \mathrm{~g} / \mathrm{L}$ (with normal levels of other immunoglobulins); normal red cell folate, 896 nmol/L (normal 400 to 1600 ); and normal vitamin $B_{12}, 586 \mathrm{pmol} / \mathrm{L}$ (normal 150 to 600 ). Although serum calcium levels were normal, 25-hydroxy-vitamin D was $35 \mathrm{nmol} / \mathrm{L}$ (normal 40 to
185) and 1,25-dihydroxy-vitamin D was $95 \mathrm{pmol} / \mathrm{L}$ (normal 36 to 119). Bone densitometry studies revealed changes consistent with early osteoporosis. A liver biopsy revealed features consistent with primary biliary cirrhosis, a condition previously associated with adult celiac disease and reported by other investigators elsewhere (10-22).

Because of diarrhea, endoscopic studies of the upper and lower gastrointestinal tracts were done and were normal. Small intestinal biopsies from the proximal small bowel, however, showed typical changes consistent with celiac disease. Gastric and colonic mucosal biopsies failed to show changes of lymphocytic gastritis (23), or collagenous or lymphocytic colitis $(24,25)$. A gluten-free diet resulted in resolution of the patient's diarrhea, weight gain of $6 \mathrm{~kg}$ and normalization of her small intestinal biopsies, resulting in the typical histological features of treated celiac disease.

Additional Coast Salish familial historical data revealed a 10 -year-old insulin-dependent diabetic daughter; in addition, the patient's sister and twoyear-old nephew were diagnosed as diabetic. The nephew, a first-degree relative, also developed diarrhea, and small intestinal biopsies done at another teaching hospital showed features typical of childhood celiac disease.

\section{DISCUSSION}

The native patient described in the present report had both celiac disease and primary biliary cirrhosis, two conditions that have previously been observed to coexist in over 20 patients from other populations (10-22). In addition, both conditions are often associated with a range of other disorders having an immunological basis $(21,26)$, including diabetes and thyroiditis, although evidence for a common genetic predisposition or a common immunological alteration has not yet been identified. Weight loss, malabsorption, bone disease, steatorrhea and elevated alkaline phosphatase activities are common features of both diseases so that at an early stage of their coexistence, celiac disease or primary biliary cirrhosis may not readily be recognized. In all patients reported with both conditions, regardless of geographical origin or race, restriction of dietary gluten caused cessation of diarrhea, as in the patient reported here, but abnormal liver chemistry tests were not improved despite a gluten-free diet.

A number of theories have been considered to explain the concomitant presence of celiac disease and primary biliary cirrhosis. One suggests that immune complexes are formed with a common antigenic basis, and this mechanism mediates tissue damage; no specific antigen, however, has been identified. Alternatively, diminished function of suppressor $\mathrm{T}$ cells in patients with both diseases might allow effector cytotoxic lymphocytes to attack a modifying antigen, such as gluten. These effector cells might then recognize and attack a patient's histocompatibility antigens, present in high concentrations in biliary as well as intestinal epithelial cells (23). Further studies are needed, however, to elucidate the very intriguing relationship between celiac disease and primary biliary cirrhosis.

The recognition of celiac disease in this native patient has particular interest as a 'new' disorder appearing for the first time in this population. The Coast Salish seemed to have survived and attained one of the highest known levels of cultural complexity, subsisting largely on fishing as well as gathering of roots and berries, rather than horticulture or herds (27). As a result of their rich, maritime temperate zone habitat, these peoples developed societies with permanent houses in villages of more than 1000 residents, social stratification with slaves and ranked nobility, elaborate ceremonies, multiple linguistic dialects and one of the world's great art styles (27). Early descriptions are reported to describe the Coast Salish tribes as a hunting and fishing peoples without knowledge of soil cultivation methods (28). Although possible sources of potato and wheat cultivation may have been Russian settlements in Alaska or some Spanish settlements at Nootka Sound in British Columbia, most historical evidence suggests that 
the Coast Salish tribes acquired some cultivation techniques only after the establishment of Fort Langley in 1827 by the Hudson's Bay Company. This was followed by very rapid diffusion of the methods elsewhere in British Columbia (29). Previously, access to Euro-

\section{REFERENCES}

1. Cooke WT, Holmes GKT. Definition and epidemiology. In: Coeliac Disease. New York: Churchill Livingstone, 1984:10-22.

2. Mylotte M, Egan-Mitchell B, Fottrell $\mathrm{PF}, \mathrm{McNicholl} \mathrm{B,} \mathrm{McCarthy} \mathrm{CF.}$ Incidence of coeliac disease in the West of Ireland. Br Med J 1973;1:703-5.

3. Simoons FJ. Coeliac disease as a geographic problem. In: Food, Nutrition and Evolution. Walcher DN, Kretchmer N, eds. New York: Masson, 1981:179-99.

4. Kagnoff MF. Role of environmental and genetic factors in celiac disease. In: Branski D, Rozen P, Kagnoff MF, eds. Gluten-sensitive Enteropathy. Frontiers in Gastrointestinal Research, vol 19. Basel: Karger, 1992:15-28.

5. Auricchio S, Visakorpi JK. Common food intolerances 1: Epidemiology of coeliac disease. In: Paubert-Braquet M, ed. Dynamic Nutrition Research, vol 2. Basel: Karger, 1992:1-187.

6. Sagaro E, Jiminez N. Family studies of coeliac disease in Cuba. Arch Dis Child 1981;56:132-3.

7. Suliman GI. Coeliac disease in Sudanese children. Gut 1978;19:121-5.

8. McNeish AS, Rolles CJ, Nelson R, Kyaw-Myint TO, MacKintosh P, Williams AF. Factors affecting the differing racial incidence of coeliac disease. In: Hekkens TJM, Pena AS, eds. Coeliac Disease. Leiden: Stenfert Kroese, 1974:330-7.

9. Logan RFA. Epidemiology of coeliac disease. In: Marsh MN, ed. Coeliac Disease. Oxford: Blackwell Scientific Publishers, 1992:192-214.

10. Logan RFA, Ferguson A, Finlayson peans was very limited. This recent and very significant change from a foodgathering society to an agricultural food-producing society apparently occurred rapidly in these aboriginal peoples. Although heritable factors for celiac disease are clearly important in

DNC, Weir DG. Primary biliary cirrhosis and coeliac disease - an association? Lancet 1978;i:230-3.

11. Craxi A, Pinzello G, Oliva A, Pagliaro L. Primary biliary cirrhosis and coeliac disease. Lancet 1978;i:713.

12. Lee FI, Murray SM, Norfolk D, Vasudev KS. Primary biliary cirrhosis and coeliac disease. Lancet 1978;i:716.

13. Iliffe GD, Owen DA. An association between primary biliary cirrhosis and coeliac disease. Dig Dis Sci 1979;24:802-6.

14. Olsson R, Kagevi I, Rydberg L. On the concurrence of primary biliary cirrhosis and jejunal villous atrophy resembling coeliac disease. Scand J Gastroenterol 1982;17:625-8.

15. Shanahan F, O'Regan PF, Crowe JP. Primary biliary cirrhosis associated with coeliac disease. Ir Med J 1983;76:282.

16. Scrhrijver G, Van Berge Henegouwen GP, Bronkhorst FB. Gluten-sensitive coeliac disease and primary biliary cirrhosis syndrome. Neth J Med 1984;27:218-21.

17. Gabrielsen TO, Hoel PS. Primary biliary cirrhosis associated with coeliac disease and dermatitis herpetiformis. Dermatologica 1985;170:31-4.

18. Lofgren J, Jarnerot G, Danielsson D, Hemdal I. Incidence and prevalence of primary biliary cirrhosis in a defined population in Sweden. Scand J Gastroenterol 1985;20:647-50.

19. Fouin-Fortunet H, Duprey F, Touchais O, Hemet J, Galmiche JP, Colin R. Celiac disease associated with primary biliary cirrhosis. Gastroenterol Clin Biol 1985;9:641-2.

20. Behr W, Barnert J. Adult celiac disease the clinical expression of this disorder, recent environmental changes during the past century, including the introduction of wheat cultivation methods, may be relevant in the pathogenesis of celiac disease in this particular population.

and primary biliary cirrhosis. Am J Gastroenterol 1986;81:796-9.

21. Whitehead EM, Daily JG, Hayes JR. Renal tubular acidosis in association with Sjogren's syndrome, primary biliary cirrhosis and coeliac disease. Ir Med J 1987;156:124-5.

22. Ginn P, Workman RD. Primary biliary cirrhosis and adult celiac disease. West J Med 1992;156:547-9.

23. Wolber R, Owen D, DelBuono L, Appelman H, Freeman HJ. Lymphocytic gastritis in patients with celiac sprue or sprue-like intestinal disease. Gastroenterology 1990;95:310-5.

24. Freeman HJ. Collagenous inflammatory mucosal diseases of the gastrointestinal tract. Can J Gastroenterol 1990;4:196-200.

25. Wolber R, Owen D, Freeman HJ. Colonic lymphocytosis in patients with celiac sprue. Hum Pathol 1990;21:1092-6.

26. Cooper BT, Holmes GK, Cooke WT. Coeliac disease and immunological disorders. Br Med J 1978;1:537-9.

27. Suttles W. Coping with abundance: Subsistence on the northwest coast. In: Suttles W, ed. Coast Salish Essays. Seattle: University of Washington Press, 1987:45-63.

28. Suttles W. The early diffusion of the potato among the Coast Salish. In: Suttles W, ed. Coast Salish Essays. Seattle: University of Washington Press, 1987:137-51.

29. Harris C. The lower mainland, 1820-81. In: Wynn G, Oke T, eds. Vancouver and Its Region. Vancouver: University of British Columbia Press, 1992:38-68. 


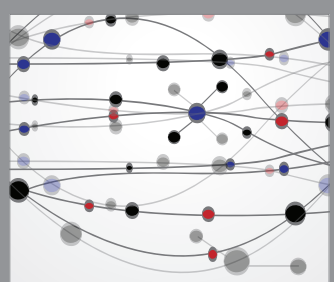

The Scientific World Journal
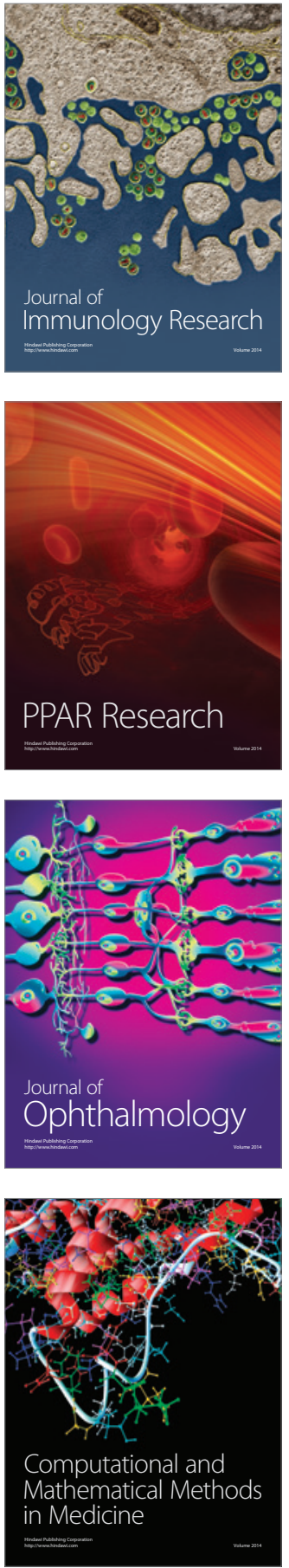

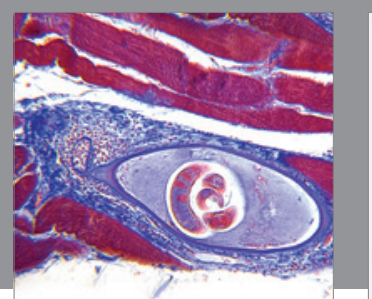

Gastroenterology Research and Practice

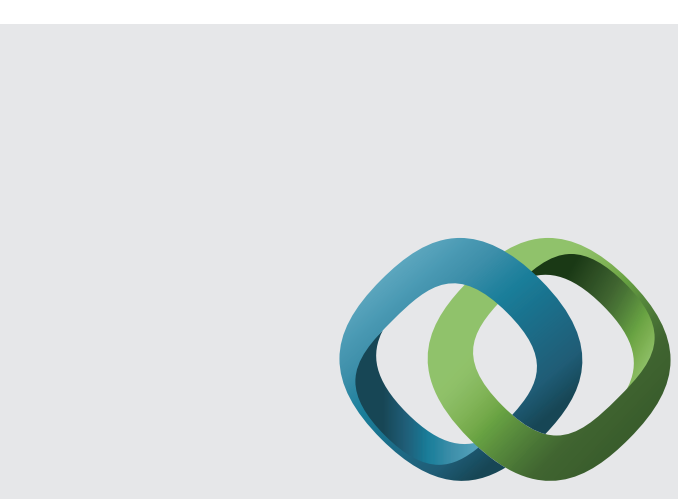

\section{Hindawi}

Submit your manuscripts at

http://www.hindawi.com
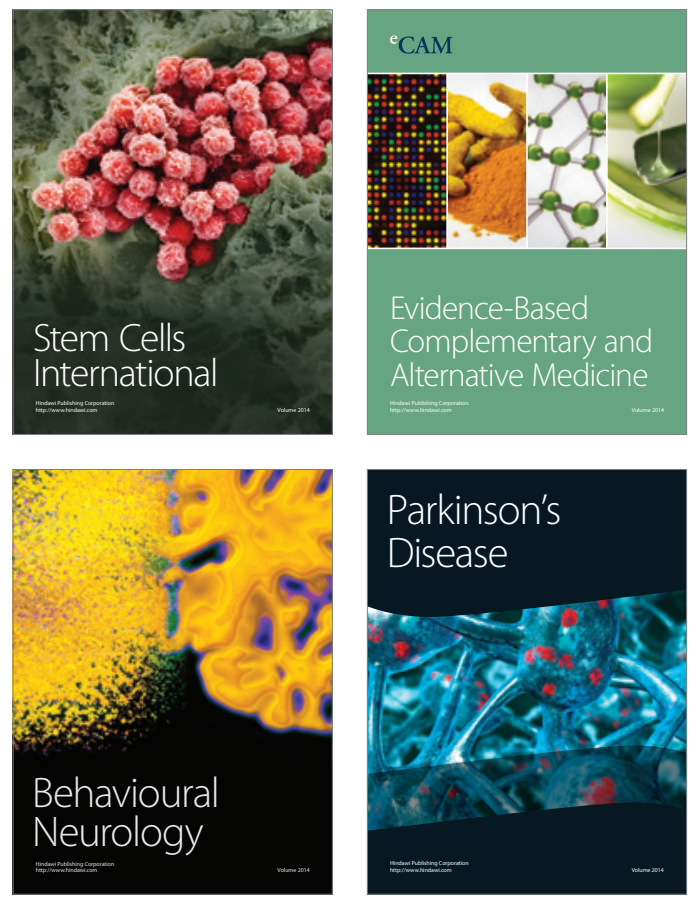
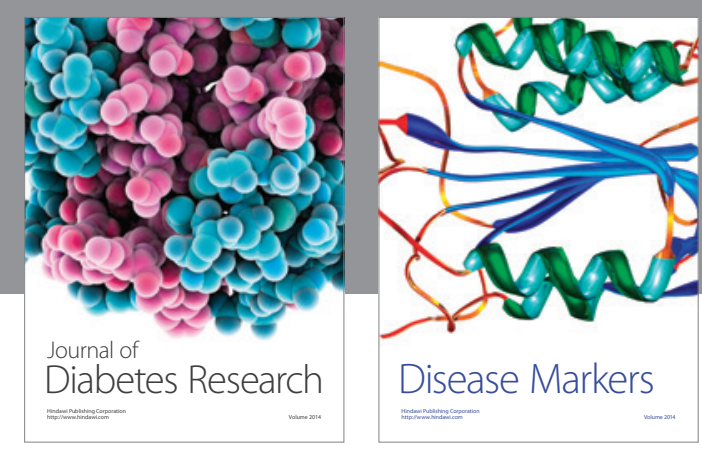

Disease Markers
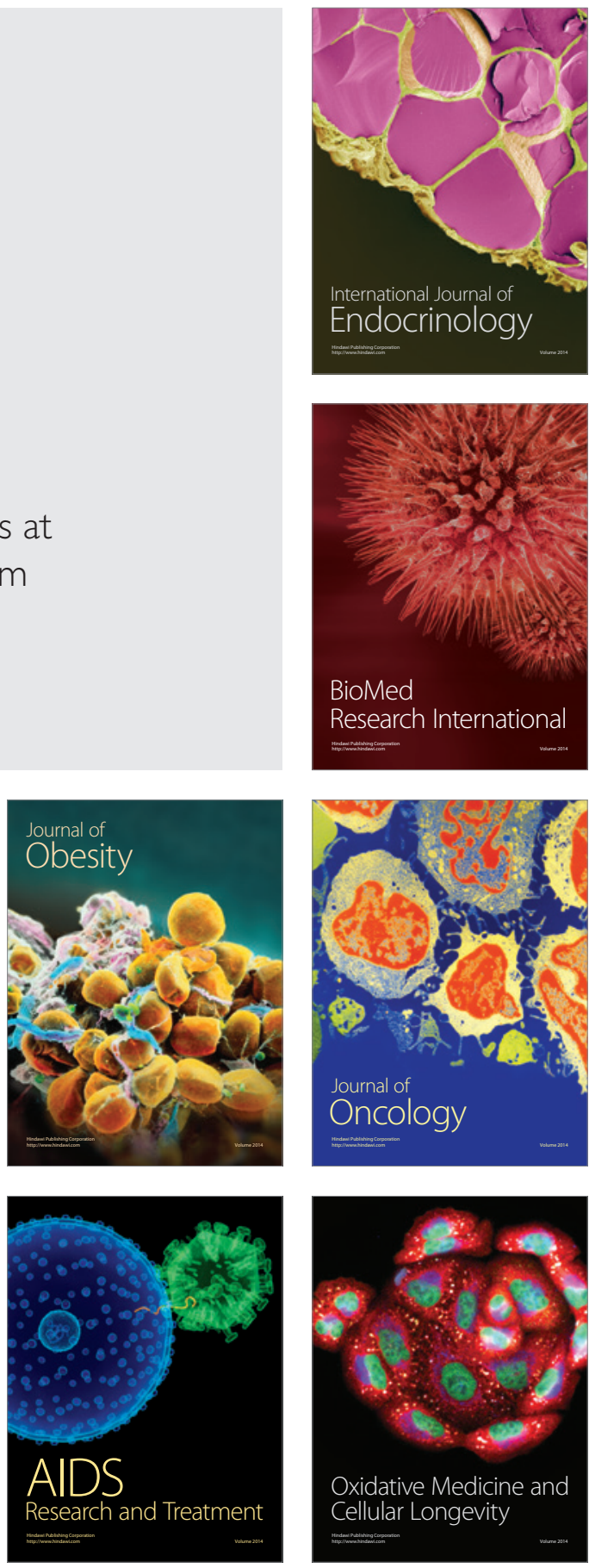